\title{
Botulinum toxin in the treatment of post-traumatic headache - case study
}

\section{Toksyna botulinowa w leczeniu pourazowego bólu głowy - opis przypadku}

\author{
Marcela Lippert-Grüner \\ Ambulantes Neurologisches Rehabilitationszentrum, Department of Neurological Rehabilitation, Bonn, Germany \\ Medical Faculty, University of Cologne, Germany \\ Department of Rehabilitation Medicine, ILF Charles University, Prague, Czech Republic
}

Neurologia i Neurochirurgia Polska 2012; 46, 6: 591-594

DOI: 10.5114/ninp.2012.32109

\begin{abstract}
Pharmacotherapy of acute post-traumatic tension headaches consists of analgesics and non-steroidal anti-inflammatory drugs (NSAIDs). Treatment of chronic tension-type headaches consists mainly of tricyclic antidepressants; local injection of botulinum toxin is one of the comparatively newer therapeutic options. No data on the treatment of post-traumatic headaches with botulinum toxin exist.

A 62-year-old woman with a history of major traumatic brain injury five years previously developed chronic tension-type headaches of an oppressive nature. The results of treatment with oral medication were not satisfactory. The patient was treated with local injections of 22 IU Botox ${ }^{\circledR}$ into the frontalis muscle and corrugator supercilii muscle. After only five days, the headaches had improved and after ten days the patient was free of symptoms even when under stress.

Sufficiently large-scale clinical studies are now required to better evaluate the effects of botulinum toxin on post-traumatic headaches.
\end{abstract}

Key words: botulinum toxin, post-traumatic headache, traumatic brain injury.

\section{Introduction}

Traumatic brain injury (TBI) is common. The annual incidence of this condition is $180-200 / 100000$ in

\section{Streszczenie}

W farmakoterapii ostrego pourazowego bólu głowy typu napięciowego wykorzystuje się leki przeciwbólowe i niesteroidowe leki przeciwzapalne. Leczenie przewlekłych bólów głowy typu napięciowego polega głównie na podawaniu trójpierścieniowych leków przeciwdepresyjnych. Miejscowe wstrzykiwanie toksyny botulinowej jest jedną z nowszych metod leczenia. Nie ma natomiast danych dotyczących zastosowania toksyny botulinowej w pourazowych bólach głowy. U 62-letniej kobiety, która pięć lat wcześniej doznała poważnego urazu mózgu, rozwinęły się uciążliwe przewlekłe bóle głowy typu napięciowego. Leki podawane doustnie nie przyniosły zadowalającej poprawy. Pacjentkę leczono wstrzyknięciami toksyny botulinowej (22 j. Botoksu ${ }^{\circledR}$ ) do mięśnia czołowego i mięśnia marszczącego brwi. Po upływie zaledwie 5 dni bóle głowy zmniejszyły się, a po 10 dniach pacjentka nie odczuwała bólu głowy nawet pod wpływem stresu.

Dokładniejsza ocena wpływu toksyny botulinowej na pourazowe bóle głowy będzie możliwa w badaniach klinicznych na odpowiednio dużych grupach pacjentów.

Słowa kluczowe: toksyna botulinowa, pourazowy ból głowy, urazowe uszkodzenie mózgu.

Anglo-Saxon countries, with about 300 000/80 million/year in Germany [1]. According to the literature, up to $90 \%$ of patients suffer from post-traumatic headaches [2]. Post-traumatic headaches occur more

Correspondence address: Marcela Lippert-Grüner, ANR Bonn, Graurheindorfer Strasse 149 a, 53117 Bonn, Germany

Received: 19.09.2011; accepted: 21.02.2012 
often and persist longer after mild TBI than after major head injuries. Tension-type headaches are the most common, accounting for about $85 \%$ of all cases [3-5]. Posttraumatic headaches may be either acute or chronic, the only difference being that chronic headaches persist for more than eight weeks after the patient has regained consciousness, or after the injury itself if there was no loss of consciousness [3]. Post-traumatic headaches are often associated with autonomic and neurasthenic symptoms such as dizziness, nausea, fatigue and sleep disturbances, as well as behavioural disorders, mood swings, and impairment of attention, memory or other cognitive functions [6]. If the TBI is mild with no loss of consciousness, post-traumatic headaches usually resolve completely within 6-12 weeks; with major TBI the headaches have usually disappeared within a few months, and only about $20 \%$ of those affected still suffer from headaches after three years $[4,5]$.

Pharmacotherapy of acute post-traumatic tension headaches consists of analgesics (acetylsalicylic acid, paracetamol) and non-steroidal anti-inflammatory drugs (NSAIDs), e.g. ibuprofen or naproxen $[4,5]$. However, these should not be prescribed for more than four weeks because of the risk of causing drug-induced headaches. On the other hand, treatment of chronic tension headaches consists mainly of tricyclic antidepressants such as amitriptyline, with doxepin and imipramine as alternatives or, with strict determination of the indication, a monoamine oxidase inhibitor (MAO-I), especially if there is a protracted course with chronification. In addition to medication, non-pharmacological treatment such as physiotherapy, massage, heat treatment and learning muscle relaxation techniques may be useful.
The treatment of headaches with local injections of botulinum toxin is one of the newer therapeutic options. Even though there is still no regulatory approval of this therapy, at least not in Germany, several clinical trials reporting good results on certain types of headache, including chronic tension headaches, have already been published [7-11]. To date, no data on the treatment of post-traumatic headaches exist. At present, this treatment is only registered for chronic migraine, but has no approval in other headaches, including tension-type headache.

\section{Case report}

The patient was a 62-year-old woman with a history of major TBI five years previously. She had been in a coma for eight days and had had retrograde amnesia for about 30 days. Initial cranial computed tomography (CT) showed a large frontal contusion and haematoma (Fig. 1).

Following the acute medical care, the patient received early rehabilitation for three months. She reported the predominantly frontal headaches almost immediately after regaining consciousness at the neurosurgical intensive care unit. During the first few months, the intensity of the headaches decreased from 7-8 to 3-4 on the pain scale, becoming chronic tension-type headaches of an oppressive nature 'like an iron band around the head'. The headaches persisted for five years after the trauma. Medication in the acute phase started with analgesics and NSAIDs and progressed to tricyclic antidepressants after about six weeks. This treatment was supplemented by non-pharmacological therapy (muscle relaxation

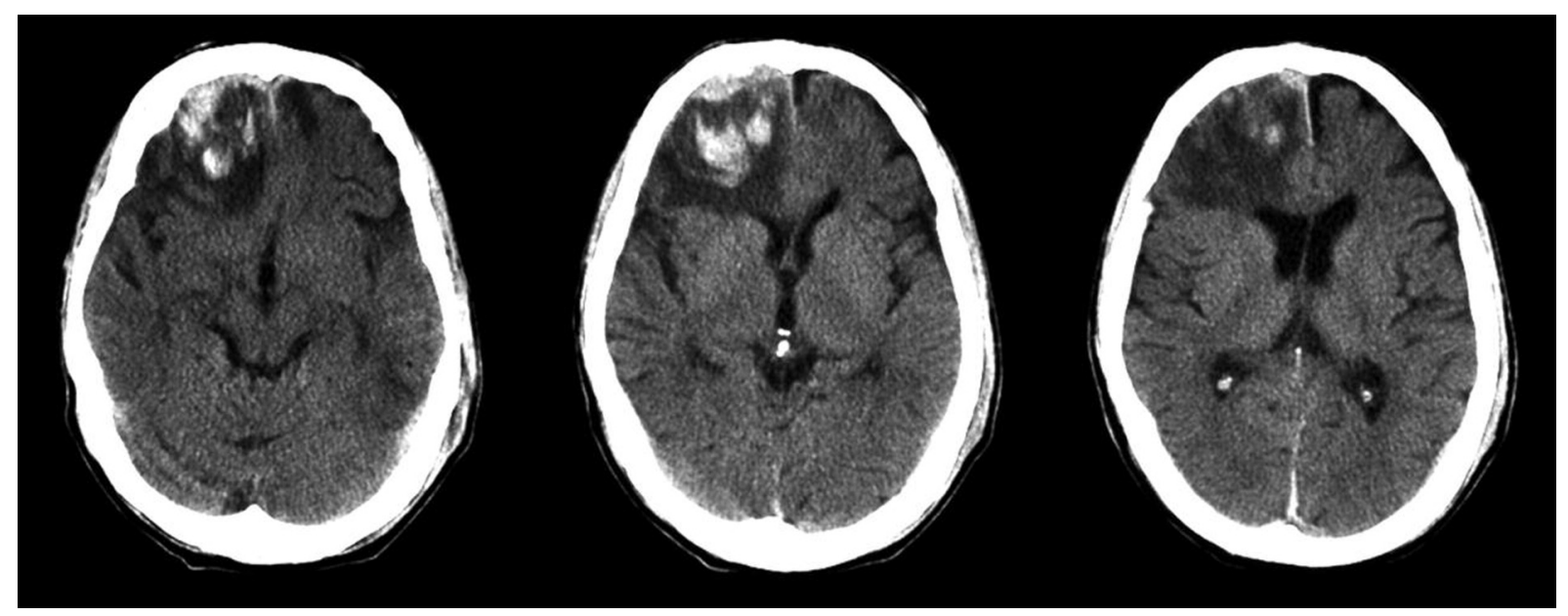

Fig. 1. Location of intracranial lesions 
exercises, heat treatment, physiotherapy, and adjuvant psychotherapy) but the results were not satisfactory. The headache occurred continually, with an intensity of 2-3 on the pain scale. Fatigue and stress exacerbated the symptoms to a pain level of 5-6. The initial rightsided hemiparesis recovered apart from mildly impaired coordination affecting mainly the arms, while the neuropsychological disorders - primarily an attention deficit - persisted despite an initial improvement with intensive neuropsychological therapy.

When she came for outpatient follow-up five years after the TBI, the patient's main complaint was the posttraumatic headache, which was adversely affecting her quality of life and greatly restricting everyday activities, in particular her social activities. She was therefore offered treatment with botulinum toxin, which she at first refused. About four weeks later, she came back asking to be given a therapeutic trial of botulinum toxin. Treatment was given with local injections of $22 \mathrm{IU}$ of onabotulinumtoxin A $\left(\right.$ Botox $\left.^{\circledR}\right)$, including four 2 IU injections into the frontalis muscle, with two $4 \mathrm{IU}$ and one 6 IU injections into the corrugator supercilii muscle. There were no complications. After only five days, the headaches had improved to just 1-2 on the pain scale, and after ten days the patient was free of symptoms even when under stress. The 'iron band' sensation also disappeared completely.

\section{Discussion}

Botulinum toxin as a treatment option for headaches was discovered really by chance, when patients who were undergoing cosmetic treatment for wrinkles on the forehead reported the reduction of headaches as a beneficial side-effect. Since then, several published studies have shown that botulinum toxin has a beneficial effect, comparable to that of amitriptyline for example, in certain types of headache [12]; on the other hand, some authors have not found any definite effects $[13,14]$. Results from exploratory trials in episodic migraine or chronic tension-type headache were equivocal but have suggested that onabotulinumtoxin A may be useful as preventive treatment for patients suffering from chronic migraine [15-20]. Results from the PREEMPT clinical trial have established onabotulinumtoxin $\mathrm{A}$ as a safe, welltolerated, and effective headache prophylactic treatment for chronic migraine [21-23]. Other placebo-controlled, exploratory studies in patients with episodic migraine brought negative results [17,24-26]. The efficacy of botulinum toxin in the treatment of cluster headache and chronic tension-type headache has not been examined in large controlled trials.

Botulinum toxin seems to be a good therapeutic option, especially for chronic headache syndromes and tension-type headaches [8-11]. In particular, the activity and tone of the pericranial muscles seem to be good predictors of treatment success [27]. Experience with local injections of botulinum toxin for post-traumatic headaches has not yet been mentioned in the literature. Given that post-traumatic headaches are common and the fact that, several years later, $20 \%$ of those affected are still suffering from chronic headaches with sometimes serious restrictions of everyday life, making social and occupational reintegration difficult, this indication for botulinum toxin therapy would be a significant addition to the available therapeutic options. It is all the more important because the therapy is almost free from adverse effects, and treatment costs with low doses of toxin certainly compare favourably with those of other medications and non-pharmacological therapies.

\section{Conclusions}

The patient reported here experienced not only a reduction in pain but also complete freedom from pain, even after five years of chronic post-traumatic headaches. This contributed to considerably greater participation in everyday and social activities and, in turn, improvement in her quality of life. Sufficiently large-scale clinical studies are now required to better evaluate the effects of botulinum toxin on post-traumatic headaches.

\section{Disclosure}

Author reports no conflict of interest.

\section{References}

1. Bouillon B., Raum M., Fach H., et al. The incidence and outcome of severe brain trauma - design and first results of an epidemiological study in an urban area. Restor Neurol Neurosci 1999; 14: 85-92.

2. Pfaffenrath V. Differenzialdiagnostische Tipps für die Praxis. So packen Sie den Kopfschmerz an der Wurzel. MMW Fortschr Med 2008; 150: 46-49.

3. Keidel M., Diener H.C. Der posttraumatische Kopfschmerz. Nervenarzt 1997; 68: 769-777.

4. Keidel M., Neu I., Langohr H.D., et al. Therapie des posttraumatischen Kopfschmerzes nach Schädel-Hirn-Trauma und HWS-Distorsion. Empfehlungen der Deutschen Migräne- und Kopfschmerzgesellschaft. Manuelle Medizin 2001; 39: 259. 
5. Keidel M. Posttraumatischer Kopfschmerz. Nervenheilkunde 2007; 26: 156-158.

6. Wacker H.R. Epidemiologie und Komorbidität von Depressionen. Therapeutische Umschau. Rev Ther 2000; 57: 53-58.

7. Jost W.H. Botulinumtoxin beim Kopfschmerz vom Spannungstyp. Fortschr Neurol Psychiatr 2003; 71: 296-299.

8. Dowson A.J., Kilminster S.G., Salt R. Clinical profile of botulinum toxin $\mathrm{A}$ in patients with chronic headaches and cervical dystonia: a prospective, open-label, longitudinal study conducted in a naturalistic clinical practice setting. Drugs $R$ D 2008; 9 : 147-158.

9. Hamdy S.M., Samir H., El-Sayed M., et al. Botulinum toxin: could it be an effective treatment for chronic tension-type headache? J Headache Pain 2009; 10: 27-34.

10. Evers S. Review of botulinum toxin type A for the prophylactic treatment of chronic daily headache. Neuropsychiatr Dis Treat 2007; 3: 761-764.

11. Chan V.W., McCabe E.J., MacGregor D.L. Botox treatment for migraine and chronic daily headache in adolescents. Neurosci Nurs 2009; 41: 235-243

12. Magalhães E., Menezes C., Cardeal M., et al. Botulinum toxin type A versus amitriptyline for the treatment of chronic daily migraine. Clin Neurol Neurosurg 2010; 112: 463-466.

13. Shuhendler A.J., Lee S., Siu M., et al. Efficacy of botulinum toxin type $\mathrm{A}$ for the prophylaxis of episodic migraine headaches: a meta-analysis of randomized, double-blind, placebo-controlled trials. Pharmacotherapy 2009; 29: 784-791.

14. De Ru J.A., Buwalda J. Botulinum toxin A injection into corrugator muscle for frontally localised chronic daily headache or chronic tension-type headache. J Laryngol Otol 2009; 123: 412-417.

15. Mathew N.T., Frishberg B.M., Gawel M., et al. Botulinum toxin type A $\left(\mathrm{BOTOX}^{\circledR}\right)$ for the prophylactic treatment of chronic daily headache: a randomized, double-blind, placebocontrolled trial. Headache 2005; 45: 293-307.

16. Freitag F.G., Diamond S., Diamond M., et al. Botulinum toxin type $\mathrm{A}$ in the treatment of chronic migraine without medication overuse. Headache 2008; 48: 201-209.

17. Silberstein S., Mathew N., Saper J., et al.; the BOTOX ${ }^{\circledR}$ Mi graine Clinical Research Group. Botulinum toxin type $\mathrm{A}$ as a migraine preventive treatment. Headache 2000; 40: 445-450.

18. Silberstein S.D., Stark S.R., Lucas S.M., et al. Botulinum toxin type A for the prophylactic treatment of chronic daily headache: a randomized, double-blind, placebo-controlled trial. Mayo Clin Proc 2005; 80: 1126-1137.

19. Aurora S.K., Gawel M., Brandes J.L., et al. Botulinum toxin type A prophylactic treatment of episodic migraine: a randomi zed, double-blind, placebo-controlled exploratory study. Headache 2007; 47: 486-499.

20. Silberstein S.D., Gobel H., Jensen R. Botulinum toxin type A in the prophylactic treatment of chronic tension-type headache: a multicentre, double-blind, randomized, placebo-controlled, parallel-group study. Cephalalgia 2006; 26: 790-800.

21. Dodick D.W., Turkel C.C., Degryse R.E. Onabotulinumtoxin A for treatment of chronic migraine: pooled results from the double-blind randomized placebo-controlled phases of the PREEMPT clinical program. Headache 2010; 50: 921-936.
22. Aurora S.K., Dodick D.W., Turkel C.C. Onabotulinumtoxin A for treatment of chronic migraine: results from the doubleblind, randomized placebo-controlled phase of the PREEMPT 1 trial. Cephalalgia 2010; 30: 793-803.

23. Diener H.C., Dodick D.W., Aurora S.K. Onabotulinumtoxin A for treatment of chronic migraine: results from the double-blind, randomized, placebo-controlled phase of the PREEMPT 2 trial. Cephalalgia 2010; 30: 804-814.

24. Saper J.R., Mathew N.T., Loder E.W., et al. A double-blind, randomized, placebo-controlled comparison of botulinum toxin type a injection sites and doses in the prevention of episodic migraine. Pain Med 2007; 8: 478-485.

25. Elkind A.H., O'Carroll P., Blumenfeld A., et al. A series of three sequential, randomized, controlled studies of repeated treatments with botulinum toxin type A for migraine prophylaxis. J Pain 2006; 7: 688-696.

26. Relja M., Poole A.C., Schoenen J., et al. A multicentre, doubleblind, randomized, placebo-controlled, parallel group study of multiple treatments of botulinum toxin type A (BoNTA) for the prophylaxis of episodic migraine headaches. Cephalalgia 2007; 27: 492-503.

27. Mitchell M.P., Schaecher K., Cannon H.E., et al. Humanistic, utilization, and cost outcomes associated with the use of botulinum toxin for treatment of refractory migraine headaches in a managed care organization. J Manag Care Pharm 2008; 14: 442-450. 